\title{
CD3e expression in HTLV-1-infected individuals is associated with proviral load and Tax expression
}

\author{
Mariana Tomazini Pinto ${ }^{1,2 *}$, Tathiane Maistro Malta ${ }^{1,2}$, Daniel Guariz Pinheiro', Evandra Strazza Rodrigues ${ }^{1,2}$, \\ Rodrigo A Panepucci ${ }^{1,3}$, Alessandra P Souza ${ }^{1}$, Kelen C R Malmegrim', Patrícia V B Palma', Osvaldo M Takayanagui ${ }^{3}$, \\ Dimas Tadeu Covas ${ }^{1,3}$, Simone Kashima ${ }^{1,2}$
}

From 15th International Conference on Human Retroviruses: HTLV and Related Viruses

Leuven and Gembloux, Belgium. 5-8 June 2011

\section{Introduction}

CD4+ T cells play a central role in HTLV-1 infection. We investigated the global gene expression profile of circulating CD4+ T cells in distinct clinical status of HTLV-1infected individuals in regard to Tax expression levels.

\section{Methods}

The microarray platform used 12 individual samples divided according to patients' clinical status and Tax expression as follows: healthy control $(\mathrm{CT}, \mathrm{n}=4), \mathrm{HAC}$ ( $\mathrm{n}=4,2$ high Tax expression and 2 low Tax expression) and HAM/TSP group $(\mathrm{n}=4,2$ high Tax expression and 2 low Tax expression). Proviral load (PVL) was quantified by qRT-PCR and Tax expression was analyzed by flow cytometry in HAC and HAM/TSP group.

\section{Results}

Hierarchical clustering analysis showed that CT and HTLV-infected groups clustered separately. We also observed that HAC and HAM/TSP groups were in separate clusters regardless Tax expression. We identified 449 genes differentially expressed between HAC and HAM/TSP groups and we classified these genes according the biological functions. CD3e was represented in many functions like cellular development, cell signaling, and others. CD3e expression by qRT-PCR was higher (1.3X) in the HAM/TSP than HAC group $(p=0.0195)$. We also validated LCK, VAV and ZAP70 genes, which are downstream molecules of the CD3e activation pathway. These genes were also significantly higher in HAM/TSP group and CD3e, LCK and VAV1 genes were positively correlated with PVL and Tax expression.

* Correspondence: matomazini@hemocentro.fmrp.usp.br

${ }^{1}$ Regional Blood Center of Ribeirão Preto, Ribeirão Preto, Brazil

Full list of author information is available at the end of the article

\section{Conclusion}

The higher PVL and Tax expression the higher activity of CD4+ T cells in the symptomatic group, suggesting that this pathway could have an important role in HAM/TSP development.

\section{Acknowledgements}

Financial support: FUNDHERP, CTC, INCTC, FAPESP, CNPq and CAPES.

\section{Author details}

'Regional Blood Center of Ribeirão Preto, Ribeirão Preto, Brazil. ${ }^{2}$ Faculty of Pharmaceutical Sciences of Ribeirão Preto, University of São Paulo, Ribeirão Preto, Brazil. ${ }^{3}$ Faculty of Medicine of Ribeirão Preto, University of São Paulo, Ribeirão Preto, Brazil.

Published: 6 June 2011

doi:10.1186/1742-4690-8-S1-A114

Cite this article as: Pinto et al: CD3e expression in HTLV-1-infected individuals is associated with proviral load and Tax expression.

Retrovirology 2011 8(Suppl 1):A114.

Submit your next manuscript to BioMed Central and take full advantage of:

- Convenient online submission

- Thorough peer review

- No space constraints or color figure charges

- Immediate publication on acceptance

- Inclusion in PubMed, CAS, Scopus and Google Scholar

- Research which is freely available for redistribution 